\title{
CORROSION OF LEAD SHIELDING IN NUCLEAR MATERIALS PACKAGES
}

\author{
K. H. Subramanian \\ Savannah River National Laboratory \\ Bldg 773-A, D-1123 \\ Aiken SC 29808 \\ K. A. Dunn \\ Savannah River National Laboratory \\ Bldg 773-41A, Rm. 182 \\ Aiken SC 29808
}

\section{ABSTRACT}

Inspection of United States-Department of Energy (US-DOE) model 9975 nuclear materials shipping package revealed corrosion of the lead shielding induced by off-gas constituents from organic components in the package. Experiments were performed to determine the corrosion rate of lead when exposed to off-gas or degradation products of these organic materials. The results showed that the room temperature vulcanizing (RTV) sealant was the most corrosive organic species followed by the polyvinyl acetate (PVAc) glue. The fiberboard material induced corrosion to a much lesser extent than the PVAc glue and RTV, and only in the presence of condensed water. The results indicated faster corrosion at temperatures higher than ambient and with condensed water as expected. A corrosion rate of $0.05 \mathrm{~mm} / \mathrm{year}$ measured for coupons exposed to the most aggressive conditions was recommended as a conservative estimate for use in package performance calculations.

\section{INTRODUCTION}

The United States Department of Energy (US-DOE) model 9975 package is a certified package for shipping of nuclear materials in the USA. The 9975 package design includes two stainless steel containment vessels designed and fabricated in accordance with Section III of the ASME Boiler \& Pressure Vessel Code. The 9975 package design also includes a lead shield to 
lower the package surface dose rate.

\section{Package Configuration}

The 9975 package is shown in Figure 1 with the materials of construction for each of the major features listed in Table 1.

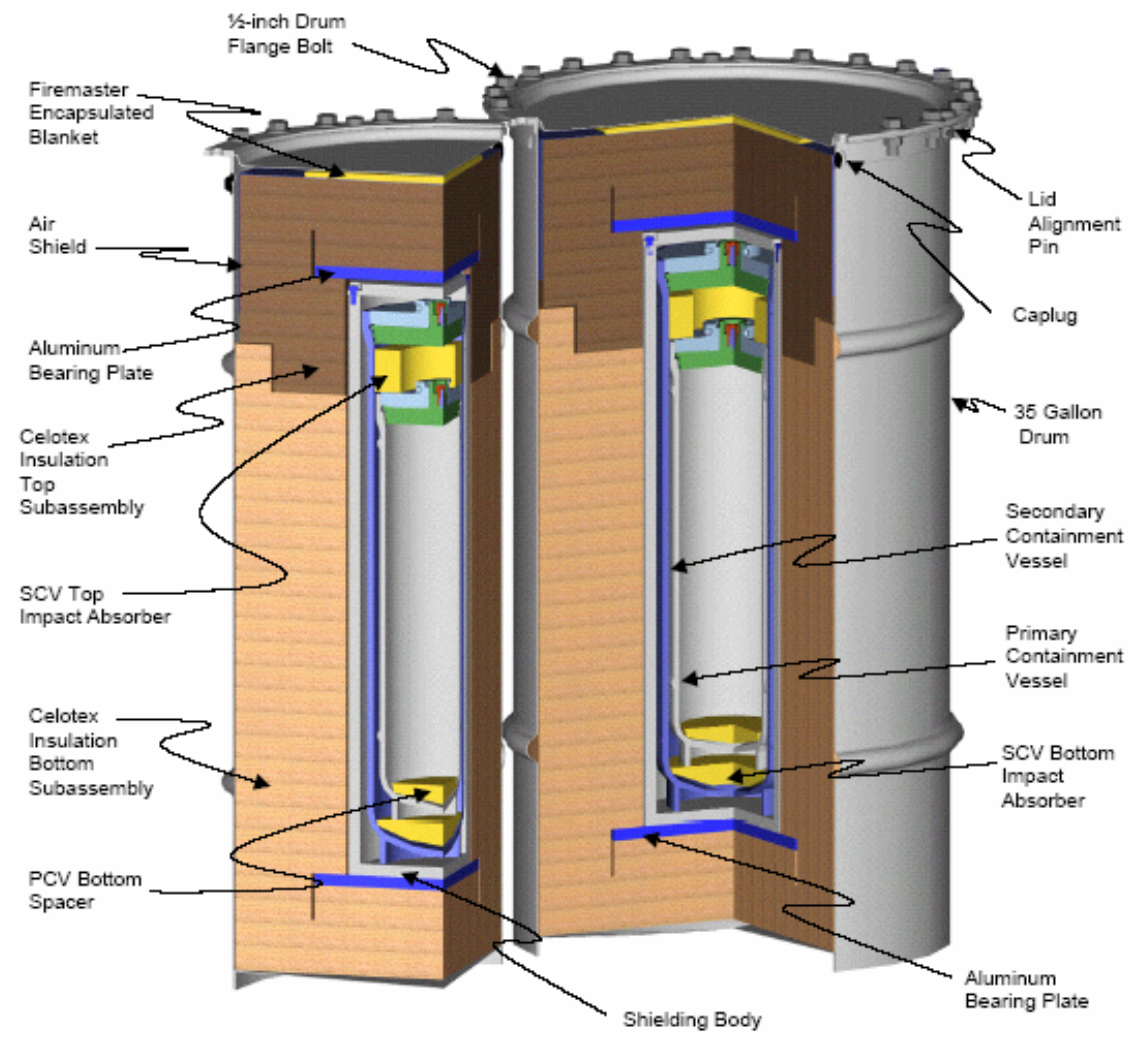

Figure 1: 9975 Package Isometric

The primary containment vessel (PCV), secondary containment vessel (SCV), and the outer drum are made of 304L-stainless steel. The containment vessels are encased in lead shielding which is encased in cane-fiberboard/PVAc laminate comprised of the top and bottom sub-assemblies. The cane-fiberboard, which adheres to ASTM C208-95:Grade IV wall sheathing, provides two safety functions: thermal insulation to limit PCV/SCV temperature during a fire, and mechanical resistance to package crushing. Layers of the cane-fiberboard are 
laminated together with a wood glue, a water-based polyvinyl acetate (PVAc) adhesive. The cane-fiberboard is nominally composed of cellulose $(\leq 96 \%)$, starch $(\leq 10 \%)$, clay $(\leq 2 \%)$, carbon black $(<0.5 \%)$, paraffin wax binder $(\leq 2 \%)$ and a lamination adhesive $(\leq 3.5 \%)$. The air shield is attached to the cane-fiberboard insulation sub-assembly with a silicone rubber sealant.

Table 1: Primary Materials of Construction of 9975 Package

\begin{tabular}{|c|c|}
\hline Component & Material \\
\hline Drum & Stainless Steel 304L \\
\hline Insulation & Cane fiberboard \\
\hline Shielding & ASTM B749 Lead \\
\hline Shield Liner & Stainless Steel 304 \\
\hline $\begin{array}{c}\text { Secondary Containment Vessel } \\
\text { (SCV) }\end{array}$ & Stainless Steel 304L \\
\hline $\begin{array}{c}\text { Primary Containment Vessel } \\
\text { (PCV) }\end{array}$ & Stainless Steel 304L \\
\hline
\end{tabular}

The cane-fiberboard/PVAc laminate is layered axially within the stainless drum. In this orientation, the outer surface of the lead cylinder is exposed to the laminate edge. The top of the lead shielding body is an aluminum lid which contacts the aluminum bearing plate in the top insulation sub-assembly.

\section{Corrosion Mechanism}

Inspections of several 9975 packages revealed a white coating on the exterior surface of the lead shielding, as shown in Figure 2. An analysis of lead shielding confirmed that the corrosion was most likely due to acetic acid emissions from organic materials used in the 9975 package. ${ }^{(1)}$ Lead is highly resistant to corrosion in many environments due to the insolubility and self-healing nature of its primary protective film, $\mathrm{PbO}$. However, lead is susceptible to corrosion in the presence of acids and bases under specific conditions, such as exposure to organic acids, including acetic, chloroacetic, oxalic acid, and formic acid. ${ }^{(2)}$ In this case, acetic acid is the specific corrodant of interest, since the cellulosic organic materials can off-gas acetic 
acid due to degradation.

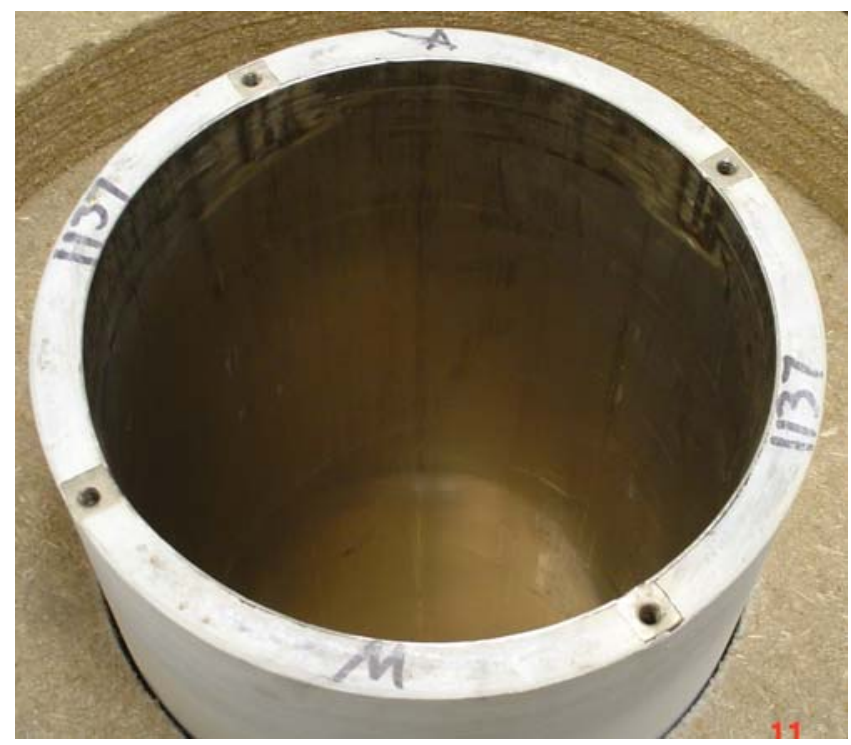

Figure 2: Lead Shielding Coated with White Materials

X-ray diffraction(XRD) was used to determine the composition of the white materials on the lead coating to determine the corrosion reactions. The XRD pattern taken from a white flake embedded in the cane-fiberboard revealed lead carbonate (cerrusite) and basic lead carbonate (hydrocerrusite), typically indicative of corrosion by acetic acid. 


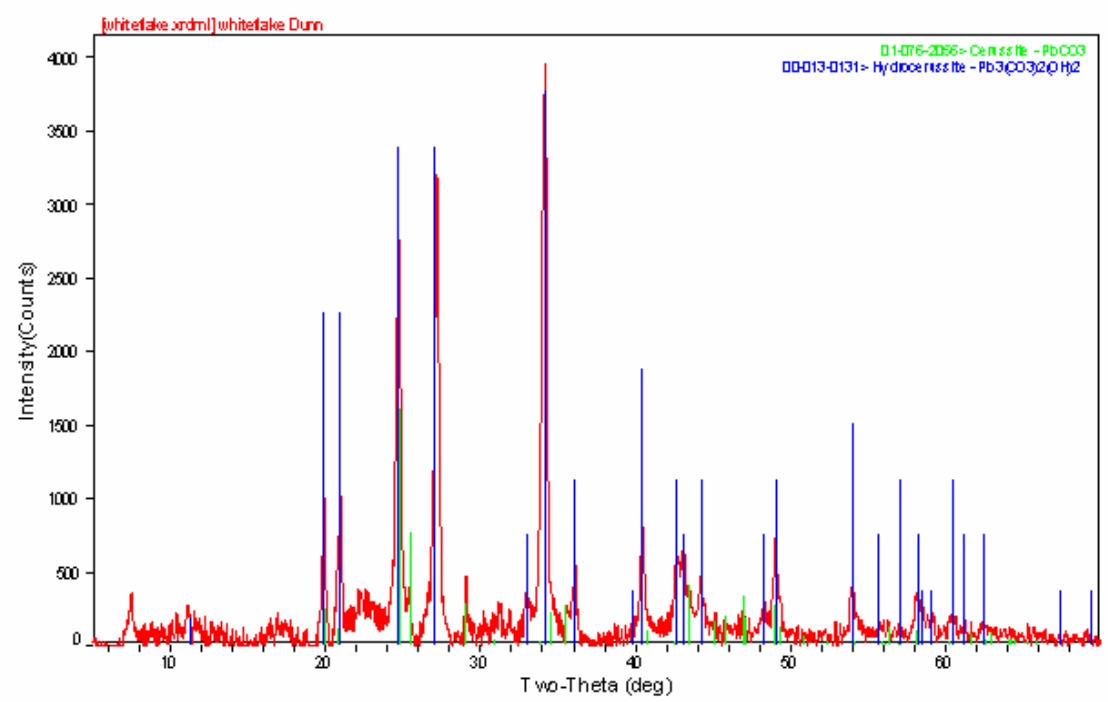

Figure 3: XRD Pattern for White Flake.

The corrosion products of cerrusite/hydrocerrusite determined by XRD are consistent with corrosion by acetic acid, in the presence of carbon dioxide, as shown in Figure 4. Acetic acid catalyzes with lead to produce lead acetate and lead hydroxide, which in turn react with carbon dioxide and form lead carbonate. Lead carbonate then releases acetic acid and the process becomes self-sustaining. ${ }^{(3)}$ In fact, the traditional method of formulating "white lead" (basic lead carbonate) for use as a white pigment, i.e. Dutch process, is to expose lead to acetic acid. $^{(4)}$

$$
4 \mathrm{CH}_{3} \mathrm{COOH}+2 \mathrm{~Pb}+\mathrm{O}_{2} \rightarrow 2 \mathrm{~Pb}\left(\mathrm{CH}_{3} \mathrm{COO}\right)_{2}+\mathrm{H}_{2} \mathrm{O} \stackrel{2 \mathrm{CO}_{2}}{\longrightarrow} 2 \mathrm{PbCO}_{3}
$$

Figure 4: Acetic Acid Corrosion of Lead ${ }^{(5)}$

The unexpected corrosion of lead due to acetic acid has been primarily reported in the context of atmospheric corrosion as seen in the museum and artifact preservation community. ${ }^{(6)}$ However, as with all atmospheric corrosion mechanisms, this is a complex function of the condensate on the lead material. The organic acids are condensed in aqueous surface film, and 
the lead carbonate compounds on the surface undergo an acid dissolution into soluble lead acetate or lead acetate oxide hydrate. The subsequent migration of this concentrated solution of acetate compounds into the cracks of the corrosion layer towards the metal surface leads to the dissolution of the $\mathrm{PbO}$ under layer, the oxidation of lead, then the peeling of the carbonate layer.

The corrosion of lead reacting with acetic acid is typically a self-sustaining process.

Acetic acid catalyzes with lead to produce lead acetate and lead hydroxide, which in turn react with carbon dioxide to form lead carbonate. Lead carbonate then releases acetic acid and the process becomes self-sustaining. ${ }^{(3)}$

Using the data shown in Table 2, it was calculated that for $1 \mu \mathrm{m}$ of lead carbonate, approximately $0.45 \mu \mathrm{m}$ of lead is lost, and for $1 \mu \mathrm{m}$ of basic lead carbonate, $0.4 \mu \mathrm{m}$ of lead is lost.

Table 2: Select Properties of Lead, Lead Carbonate, and Basic Lead Carbonate ${ }^{(7)}$
\begin{tabular}{|c|c|c|c|}
\hline & Lead & $\begin{array}{c}\text { Lead Carbonate } \\
\text { (cerrusite) }\end{array}$ & $\begin{array}{c}\text { Basic Lead } \\
\text { Carbonate } \\
\text { (hydrocerrusite) }\end{array}$ \\
\hline Chemical Symbol & $\mathrm{Pb}$ & $\mathrm{PbCO}_{3}$ & $\mathrm{~Pb}_{3}\left(\mathrm{CO}_{3}\right)_{2}(\mathrm{OH})_{2}$ \\
\hline Molecular Weight (g/mol) & 207.2 & 267.2 & 775.6 \\
\hline Density (g/cm $\left.{ }^{3}\right)$ & 11.34 & 6.6 & 6.14 \\
\hline $\begin{array}{c}\text { Moles lead consumed per } \\
\text { mole of carbonate product }\end{array}$ & -- & 1 & 3 \\
\hline
\end{tabular}

Several key data are necessary for the verification of the corrosion hypothesis and to model the short-term and long-term impact of the lead shielding corrosion on the performance of the model 9975 package. These key data include the corrosion rate of lead when exposed to an environment similar to that of a 9975 package. These exposure experiments have been conducted and the results are presented here. 


\section{EXPERIMENTAL APPROACH}

The experimental approach focused on the effect of the acetic acid emissions from organic components of the model 9975 package on the corrosion of lead. The testing included analysis of the corrosion of the lead as a function of the aging of the organic materials. The geometry of the package and the location of the corrosion indicate that the cane-fiberboard, PVAc wood glue, or the silicone are most probably involved in the corrosion process, and all may be the source of the acetic acid. The corrosion may be atmospheric in nature or in aqueous solution if the unlikely event that the annular gap between the lead and the cane-fiberboard assembly allows significant condensation.

\section{Experimental Test Matrix}

The experimental matrix was a parametric combination of the following discrete variables: (1) configuration of the organic materials, (2) temperature, (3) humidity, and (4) duration of exposure. The variables are summarized in Table 3. The configurations of the organic materials include each organic constituent uniquely to isolate their effects on the corrosion rate. The combinatory configurations include the most likely exposures in the model 9975 package.

Table 3: Summary of Discrete Variables in Parametric Test Matrix

\begin{tabular}{|c|c|c|c|}
\hline $\begin{array}{c}\text { Configuration of } \\
\text { Organic Materials }\end{array}$ & $\begin{array}{c}\text { Temperature } \\
\left({ }^{\circ} \mathbf{C}\right)\end{array}$ & Humidity & $\begin{array}{c}\text { Duration of } \\
\text { Exposure } \\
\text { (days) }\end{array}$ \\
\hline Cane Fiberboard (CF) & Ambient & Ambient & 30 \\
\hline Glue & 50 & $\begin{array}{c}\text { Condensed } \\
\text { water }\end{array}$ & 75 \\
\hline RTV & 75 & & 120 \\
\hline CF + Glue & & & \\
\hline CF + Glue + RTV & & & \\
\hline
\end{tabular}


Each of the discrete variables for exposure of the coupons was chosen on the basis of their influence on the corrosion of lead. The testing was performed by exposing lead coupons, conforming to the ASTM B749 Standard, to the various organic configurations to determine the effect of each organic component as well as synergistic effects. ${ }^{(8)}$ The temperatures tested covered the expected boundary conditions in the model 9975 package. The humidities were tested at ambient and with "condensed water" indicating a small amount of standing water thereby creating a $100 \%$ relative humidity environment. The CF materials were not dried prior to the exposure testing and any moisture retained was allowed to react. The duration of exposure was tested to determine any change in corrosion rate, or confirming the true self-sustaining nature of the corrosion phenomena. Additionally, the coupons exposed to 30 days and analyzed were placed back into exposure to simulate the opening and closing of the packages and potentially replenishing the carbon dioxide supply to further support the corrosion reaction. Cane-Fiberboard (CF)

The cane-fiberboard was nominally composed of cellulose $(\leq 96 \%)$, starch $(\leq 10 \%)$, clay $(\leq 2 \%)$, carbon black $(<0.5 \%)$, paraffin wax binder $(\leq 2 \%)$. The CF materials used for the testing were harvested from a model 9975 package spare parts assembly. A complete characterization and thermal properties of the CF was completed including compositional and thermal characterization using energy dispersive spectroscopy (EDS), inductively coupled plasma-mass spectroscopic analysis (ICP-MS), and ion chromatography (IC). ${ }^{(9)}$ The EDS data showed the presence of $\mathrm{Al}, \mathrm{Si}, \mathrm{S}, \mathrm{Cl}, \mathrm{K}, \mathrm{Ca}$, Ti and $\mathrm{Fe}$. The major anions present according to the IC data were fluoride, chloride, bromide and sulfate. IC analysis also indicated the presence of significant amount of potassium and calcium cations. The chloride concentration was measured at $960 \mu \mathrm{g} / \mathrm{g}$ whereas in other studies it has been measured up to $1800 \mu \mathrm{g} / \mathrm{g}$, both of which are a 
function of leaching parameters used. ${ }^{(10)}$ Both studies indicated that the actual chloride concentration may be much higher, certainly sufficient to cause corrosion of the stainless steel outer drum if leached. If the conditions were to support significant condensation, chloride is expected to leach out causing corrosion of the stainless steel drum, which was not evident in this case. As such, this suggests that chlorine has not leached from the CF indicating minimal condensation, if any. However the reaction rates to produce acetic acid vs. chloride leaching is unknown.

Since the primary constituent of CF is cellulose, a survey of wood as a surrogate was completed to determine the potential reactions of cellulose to create acetic acid. Wood materials are known to emit acetic acid vapor as a function of cellulose hydrolysis. ${ }^{(11)}$ The extent of the vapor emission can be a function of the initial acetic acid concentration as well as cellulose concentration. ${ }^{(12)}$ The impact of the acetic acid vapor emission on the corrosion of lead is widely known and addressed in the museum and artifact industry since the preservation of lead artifacts in wood casings has resulted in extensive corrosion. In fact, the Oddy test uses lead exposure to wood to determine the extent of acid vapor emission from specific casing designs for museum application. ${ }^{(13)}$

Polyvinyl Acetate (PVAc)

The PVAc glue is a water based thermoplastic adhesive commonly used as an emulsion of PVAc polymers in water. It is formed by polymerization of vinyl monomers in water and then cures by evaporation of water. PVAc creates strong bonds in wood but is not moisture or heat resistant unless cross-linked which consequently lowers the tack quality. ${ }^{(14)}$ The PVAc tested was not cross-linked and therefore softens at elevated temperatures and is less resistant to moisture and humidity than thermosetting resins. As a result, the use of PVAc is not 
recommended in high temperature or high humidity environments.

Another key facet of the PVAc is the availability of free hydroxyl groups since PVAc is polymerized with minor amounts of vinyl alcohol, and also can be formed by hydrolysis of the acetate groups. Vinyl acetate, the m monomer for PVAc polymerization, is also produced by catalytic oxidative condensation of acetic acid and ethylene. ${ }^{(15)}$ The hydrolysis of the PVAc creates $\mathrm{PVOH}$ and acetic acid, per the following reaction which can be accelerated by higher temperatures, and is self catalyzed by the acetic acid. ${ }^{(16)}$

$$
-\mathrm{CH}_{2} \text { - } \mathrm{CH}-\mathrm{OCOCH} \mathrm{CH}_{3}+\mathrm{H}_{2} \mathrm{O} \rightarrow-\mathrm{CH}_{2}-\mathrm{CH}-\mathrm{OH}+\mathrm{CH}_{3} \mathrm{COOH} \text { (Acetic Acid) }
$$

Experience with polyvinyl acetate has led to the recommendation that it also not be used in the museum and artifact preservation industry, because of its corrosivity towards lead in particular. ${ }^{(17)}$

\section{Silicone Based Sealant}

The silicone-based sealant is a two-part room temperature vulcanizing system (RTV) which cures via the silicone molecule's silanol ends. Silicone sealants are based on mixtures of fillers (e.g., silica), silicone polymers, cross linking components, and catalysts. The polymer has a siloxane backbone, i.e., Si-O-Si, with alkyl and alkoxy or acetoxy pendant groups. The latter are readily hydrolyzed to silanol groups $(\mathrm{SiOH})$ which form larger chains by condensation and loss of alcohol or acetic acid. When the organic groups polymerize, a volatile species is generally released - the most common being acetic acid. However, the sealant typically does not continue to off-gas acetic acid when completely cured. The sealant can release acetic acid if it degrades most likely due to hydrolysis.

Water and Carbon Dioxide

It is important to identify the source of the water vapor and the carbon dioxide in the 
package. The outer drum is not a pressure or leak tight boundary, thereby potentially allowing water vapor and air into the $\mathrm{CF}$ assembly. The $\mathrm{CF}$ has significant porosity potentially containing humid air providing water as well as the carbon dioxide for the reactions to take place. TGA-MS analysis, shown in Figure 5, of the CF indicated water physisorbed onto the surface in addition to the humidity. Measurements of the moisture content of CF in the 9975 package shows typical levels of $12-14 \%$ wood moisture equivalent. This represents equilibrium with an atmospheric humidity level of $65-75 \%$ at $70^{\circ} \mathrm{F} .^{(18)}$

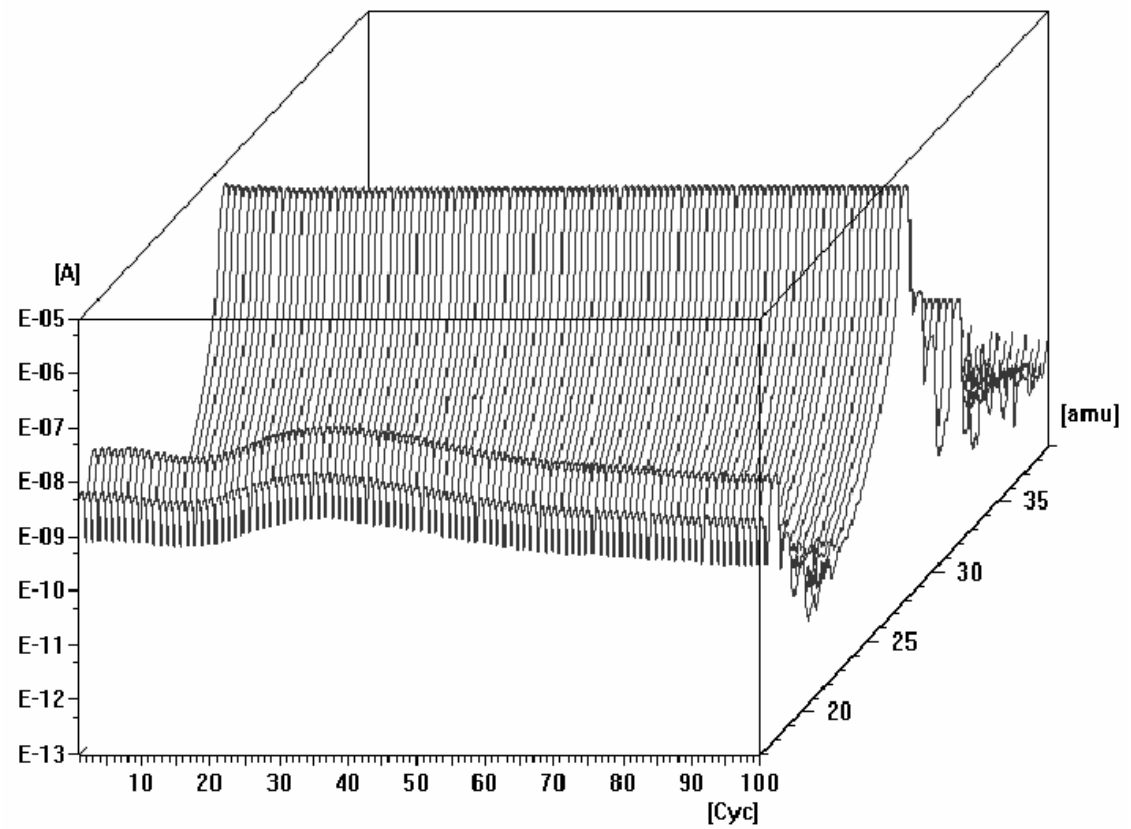

Figure 5: TGA-MS of Celotex ${ }^{\circledR}$ Sample Indicating Water Content at 18 amu

The maximum allowable water absorption is $7-15 \%$ depending upon thickness of the wall sheathing materials as outlined by ASTM Standard C208, "Standard Specification for Cellulosic Fiber Insulating Board".

\section{Experimental Setup}

Testing for each unique condition was done in a $125-\mathrm{mL}$ clear glass septa bottle. The lead coupons, nominally $3.175 \mathrm{~mm}$ were mounted on a stainless steel rack perforated base stud (Figure 6) with the organic assemblies. The organic assemblies were assembled by cutting them 
into a pattern to screw onto the coupon stud. The lead coupon was exposed to the assemblies on both sides but were separated using Teflon washers and nuts to allow for air exchange in the interface. Coupons were weighed, measured, and photographed before and after exposures.
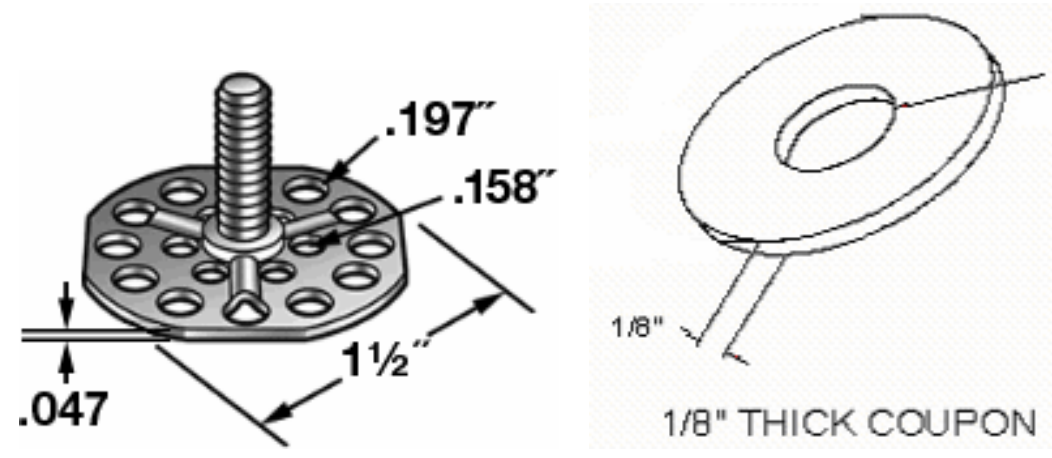

Figure 6: Perforated Base Stud Coupon Rack and Lead Coupon

The coupons were analyzed for corrosion after the exposure testing. The coating thickness was measured with a x-y traveling stage microscopy after scraping the edge to reveal the underlying lead coupon with the carbonate coating. This measured coating thickness was used to calculate the corrosion rate.

\section{RESULTS AND DISCUSSION}

The coupons were analyzed after completion of their exposures. The coupons that were exposed for 30 and 75 days were re-exposed and analyzed after 120 day to simulate the opening and closing of the package. Photographs and visual inspection were initially used to determine the presence of corrosion product. The coupons were then weighed and dimensioned. The carbonate thickness was measured when possible by scraping a portion of the edge and using an $\mathrm{x}-\mathrm{y}$ traveling microscopic stage. The corrosion rate was calculated assuming that the carbonate layer consisted of $50 \%$ cerrusite and $50 \%$ hydrocerrusite. This implies that for every $1 \mu \mathrm{m}$ of coating thickness, there is $0.425 \mu \mathrm{m}$ lead lost. The corrosion rates are all reported as amount of 
lead metal lost per unit of time. The rates were calculated using the following formula

$$
\frac{\text { CoatingThickness }(\mu \mathrm{m})}{\text { Duration }}[0.425]=\frac{\operatorname{LeadLost}(\mu \mathrm{m})}{\text { Year }}
$$

The corrosion rate was calculated for the coupons that were exposed for the complete duration of exposures and also for the coupons that were re-exposed after interim analysis. The corrosion rates for the coupons exposed to the cells with condensed water were calculated. The calculated corrosion rates are reported in Figure 7 - 15 for each of the temperatures, durations, and organic configurations tested. Rates are also reported for the coupons that were re-exposed after interim analysis.

Visual observations were made on coupons exposed to cells without condensed water, since these coupons did not exhibit measurable corrosion. The visual observations made on coupons which exhibited only minor corrosion when exposed to the cells with ambient humidity are discussed following the sections on corrosion rates.

\section{Corrosion Rate Analysis for the Coupons Exposed in Condensed Water Cells}

The corrosion rates (mm/year) for the lead coupons exposed in the condensed water cells for the complete duration of exposure are shown in Figure 7 - Figure 9, for room temperature, $50^{\circ} \mathrm{C}$, and $75^{\circ} \mathrm{C}$ respectively.

The PVAc glue induced corrosion of the lead metal, but did not sustain a linear corrosion rate as would be expected by the self-sustaining reaction. This is hypothesized to be either due to the variability of the degree of initial curing of the PVAc glue when placed into test or the consumption of available reactants during the exposure. The glue sample placed into the 30/75day test cells was observed to be poorly cured relative to the glue samples placed in the 120-day cell. Since the cells were not opened during the 120-day exposure period, the available $\mathrm{CO}_{2}$ or $\mathrm{H}_{2} \mathrm{O}$ may have been consumed sufficiently to decelerate the corrosion of the lead metal. 
Higher temperatures led to higher corrosion rates as well as corrosion of lead from exposure to only the cane fiberboard, whereas at room temperature, there was no measurable corrosion in this configuration. The corrosion rate of lead when exposed to the PVAc glue did not sustain a linear rate even at the higher temperatures.

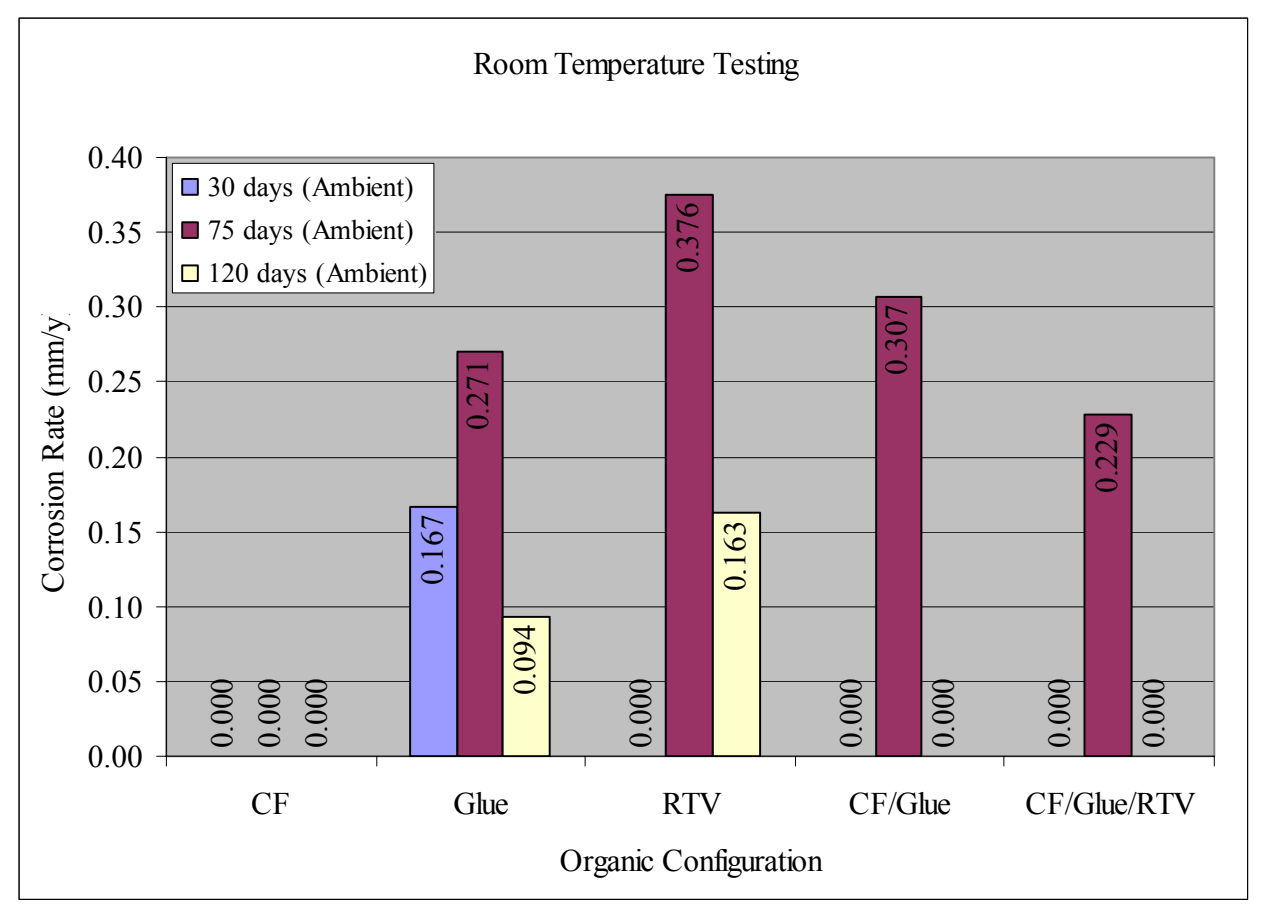

Figure 7: Corrosion Rates for Lead Coupons Exposed to Condensed Water Cells at Room Temperature for Complete Duration of Exposure

The highest corrosion rate at both of the higher temperatures tested was the $\mathrm{CF} / \mathrm{Glue} / \mathrm{RTV}$ configuration. Judging from the corrosion rate of lead when exposed only to RTV, it is hypothesized that this corrosion rate may have been induced primarily by the RTV. 


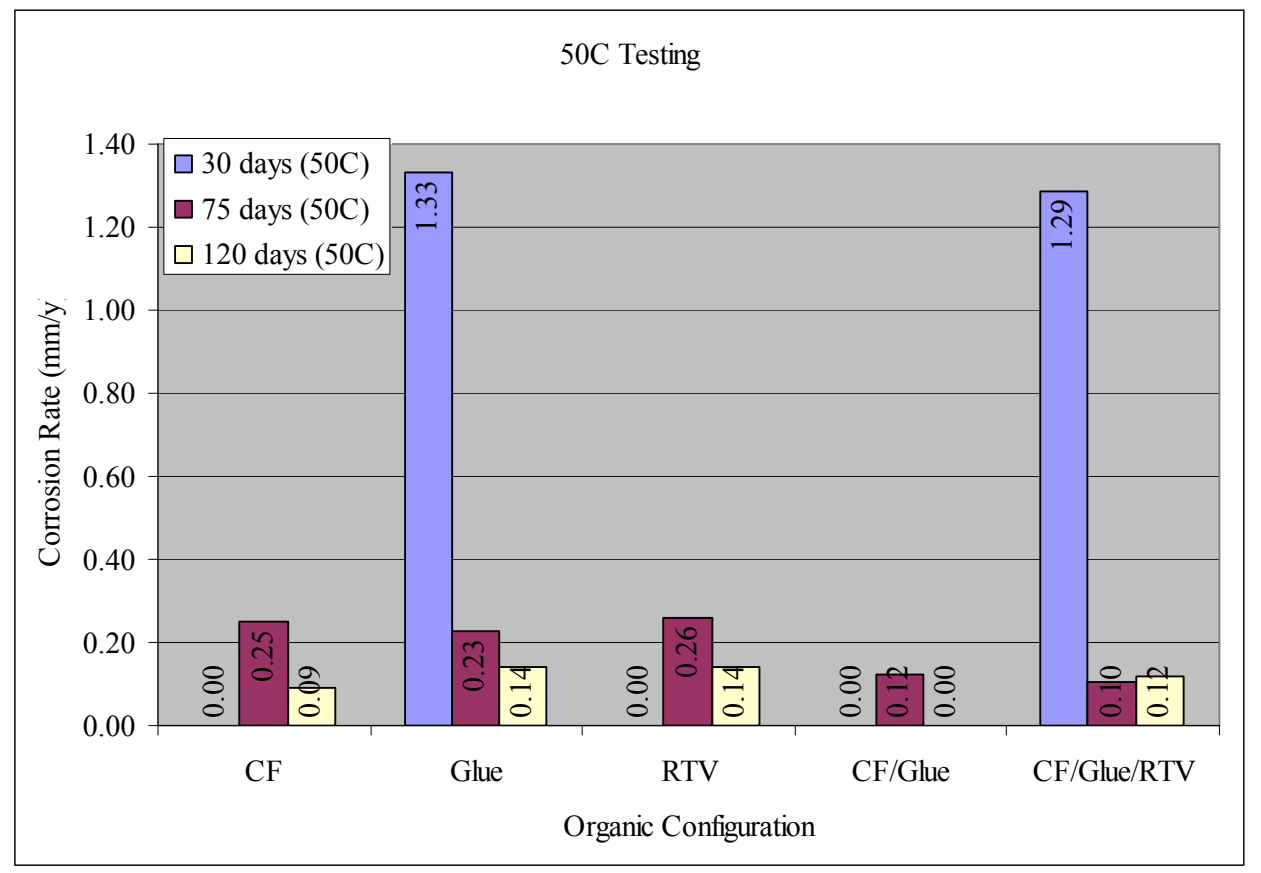

Figure 8: Corrosion Rates for Lead Coupons to Condensed Water Cells at $50^{\circ} \mathrm{C}$ for Complete Duration of Exposure

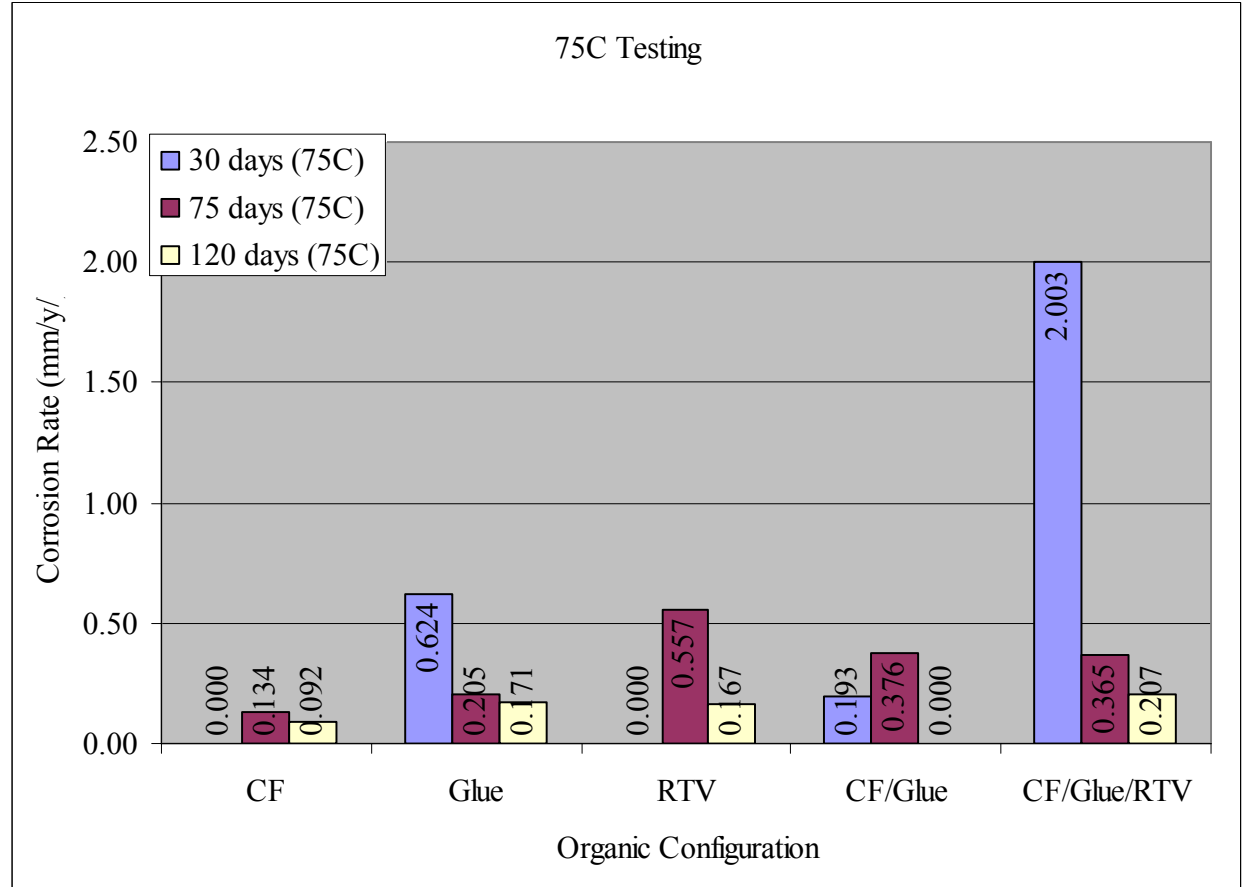

Figure 9: Corrosion Rates for Lead Coupons Exposed to Condensed Water Cells at $75^{\circ} \mathrm{C}$ for Complete Duration of Exposure

The corrosion rate data for the lead coupons exposed to the condensed water cells for the 
re-exposed coupons are shown in Figure 10 - Figure 12, for exposure at room temperature, $50^{\circ} \mathrm{C}$, and $75^{\circ} \mathrm{C}$ respectively. The 120 -day coupons are included for comparison purposes. In contrast to the initial 30-day exposures, re-exposure and replenishment of reactionary species at room temperature induced corrosion in the CF sample for the 30-day test.

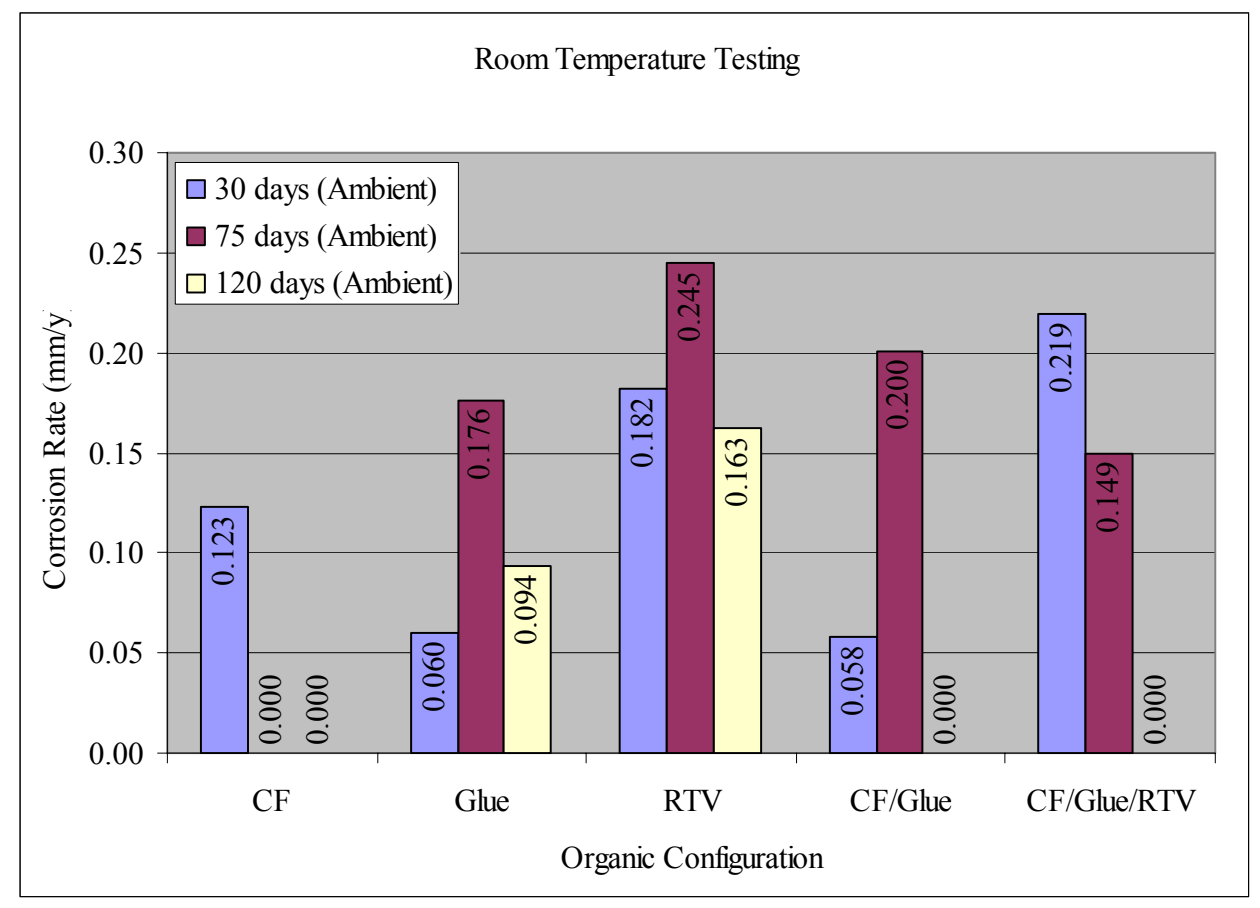

Figure 10: Corrosion Rates for Lead Coupons Exposed to Condensed Water Cells at Room Temperature for Re-Exposed Coupons and 120-Day Coupons

Corrosion was seen on all re-exposed coupons at higher temperatures, indicating that replenishment of reactionary species, i.e. $\mathrm{CO}_{2}$ and $\mathrm{H}_{2} \mathrm{O}$ may be a key factor in inducing corrosion of lead in the long-term. This is further corroborated since the re-exposed coupons exhibited higher corrosion rates than the 120-day coupons that were never removed out of test for all organic configurations. 


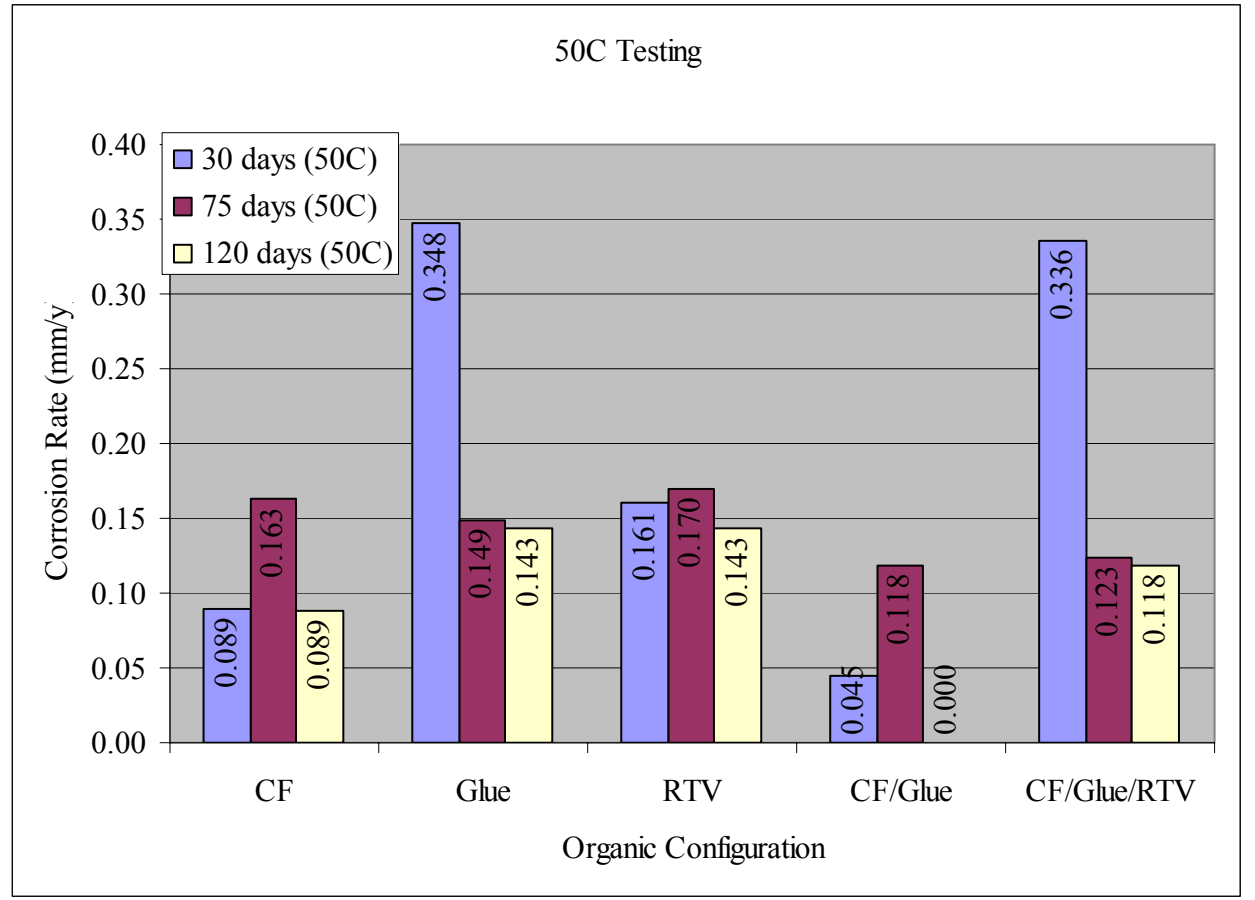

Figure 11: Corrosion Rates for Lead Coupons Exposed to Condensed Water Cells at $50^{\circ} \mathrm{C}$ for Re-Exposed Coupons and 120-Day Coupons

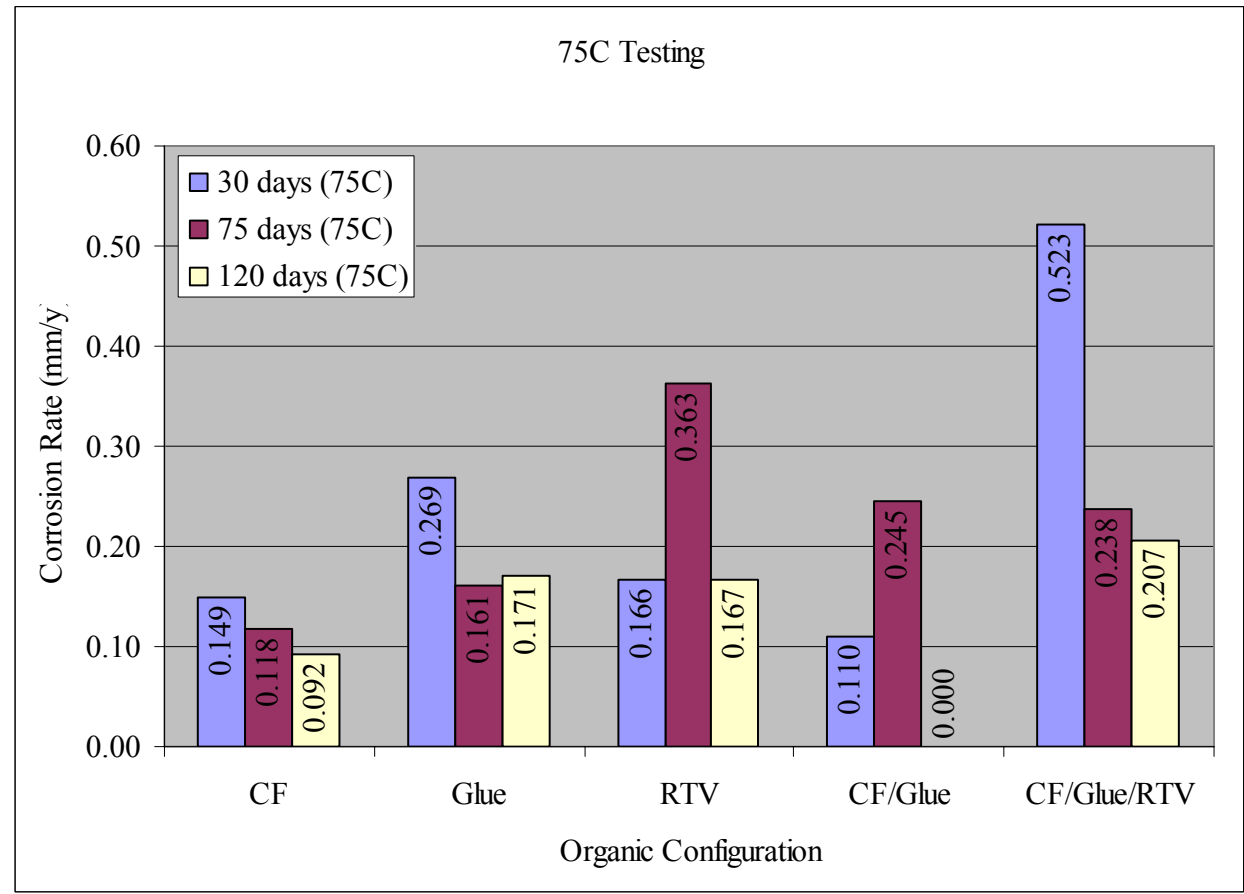

Figure 12: Corrosion Rates for Lead Coupons Exposed to Condensed Water Cells at $75^{\circ} \mathrm{C}$ for Re-Exposed Coupons and 120-Day Coupons 


\section{Corrosion Rate Analysis for the Coupons Exposed in Ambient Humidity Cells}

The corrosion rates for the ambient humidity cells were measured and calculated when possible. The lead coupons that were initially exposed for the 30/75 day cycles, then re-exposed were the only coupons that exhibited any measurable coupons. The corrosion rate data for the lead coupons exposed to the condensed water cells for the re-exposed coupons are shown in Figure 10 - Figure 12 , for exposure at room temperature, $50^{\circ} \mathrm{C}$, and $75^{\circ} \mathrm{C}$ respectively. Measurable corrosion occurred on lead coupons exposed to the glue samples in both the 30-day re-exposed coupon and the 120-day coupon.

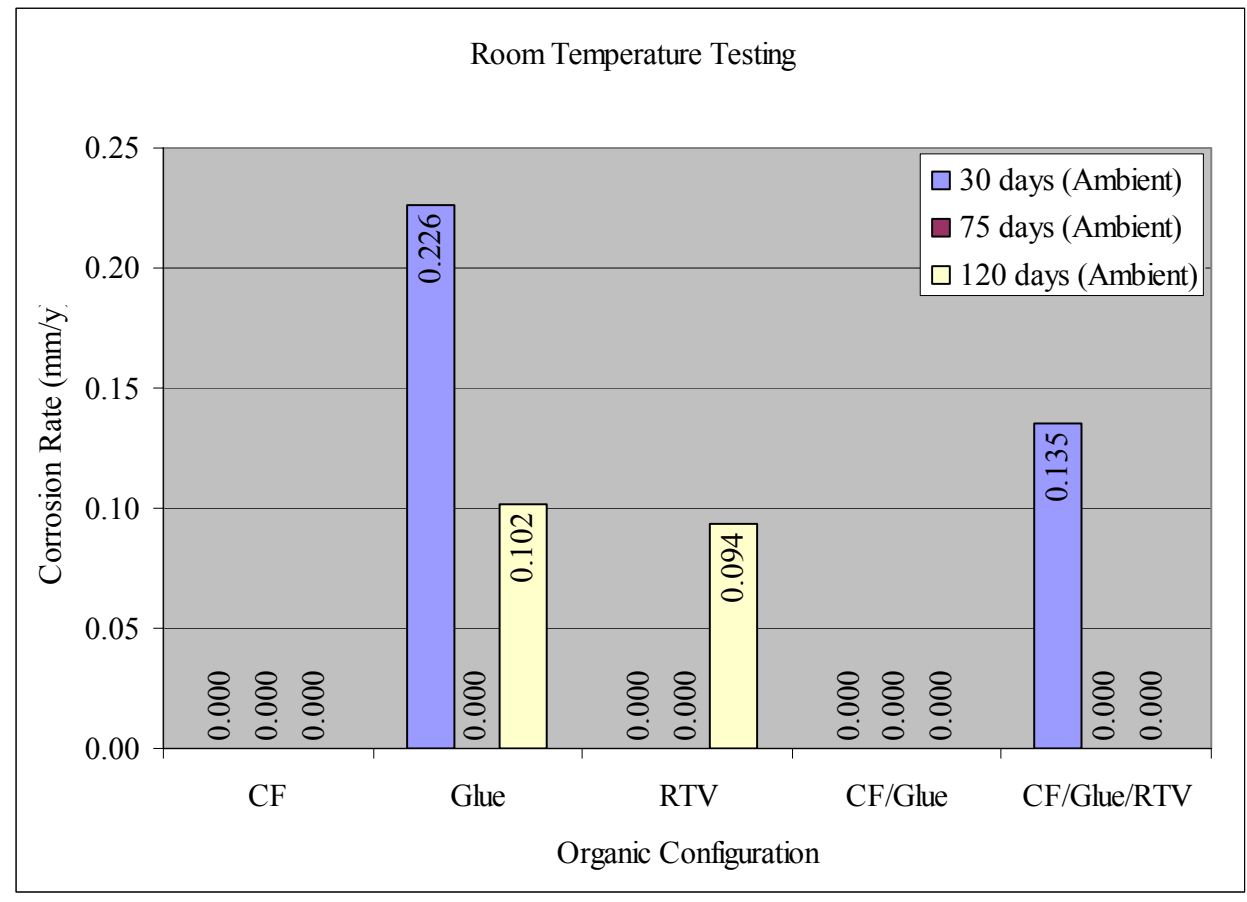

Figure 13: Corrosion Rates for Lead Coupons Exposed to Ambient Humidity Cells at Room Temperature for Re-Exposed Coupons and 120-Day Coupons

Exposure of the coupons at higher temperatures led to corrosion of lead coupons exposed to more configurations than exposure at room temperature. In addition, the higher temperatures led to higher corrosion rates. Measurable corrosion was on all coupons exposed to the RTV. However, these coupons exhibited much lower (approximately $1 / 2$ ) corrosion rates than the 
coupons exposed to similar organic configurations with condensed water as described in the previous section.

The initial integrity of the organic assembly is suspected to play a large role in the corrosion response. The initial integrity of the PVAc glue and the RTV material is dependent upon the degree of curing. Both the PVAc and RTV off-gas acetic acid as the polymerize (i.e. cure). In addition, the degree of curing controls the ability of each of these materials to resist hydrolysis and the consequent release of acetic acid.

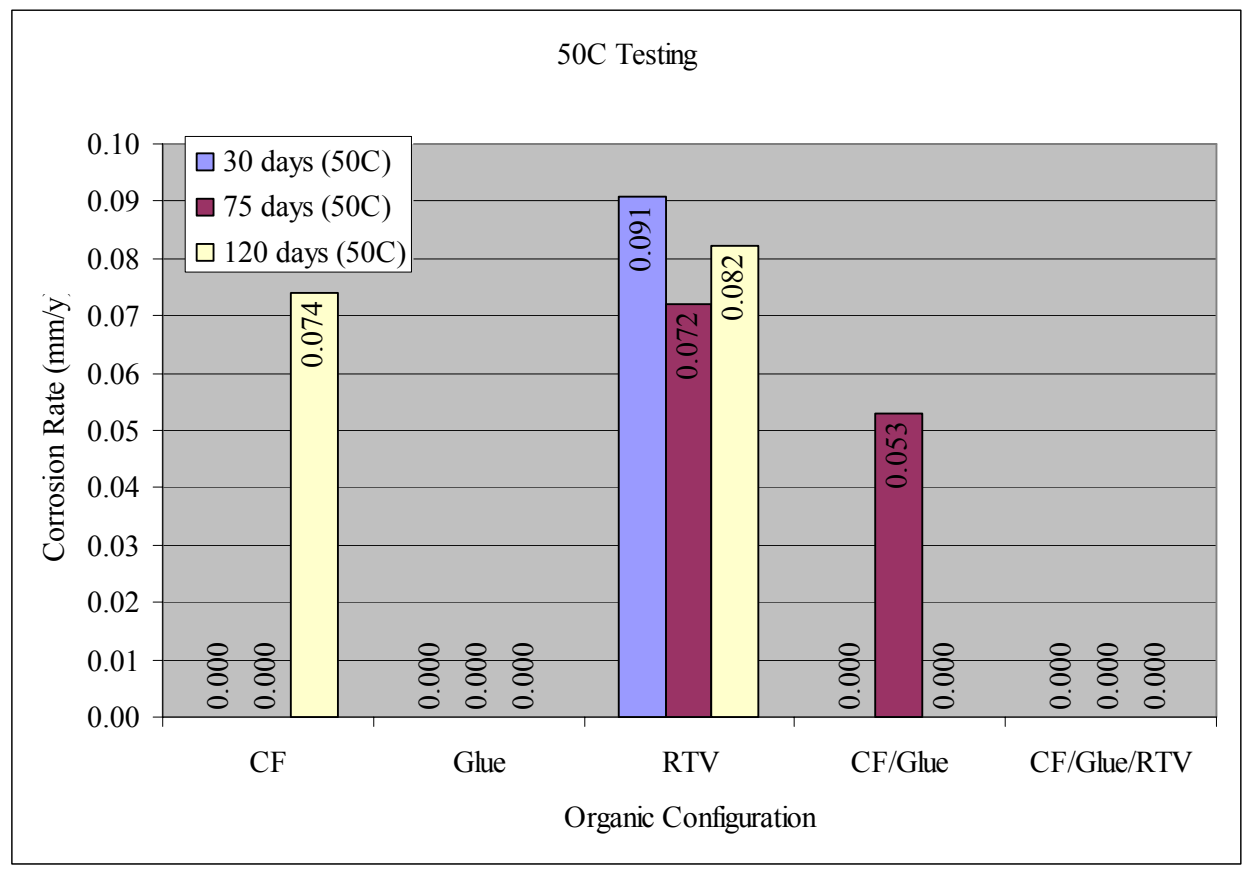

Figure 14: Corrosion Rates for Lead Coupons Exposed to Condensed Water Cells at $50^{\circ} \mathrm{C}$ for Re-Exposed Coupons and 120-Day Coupons 


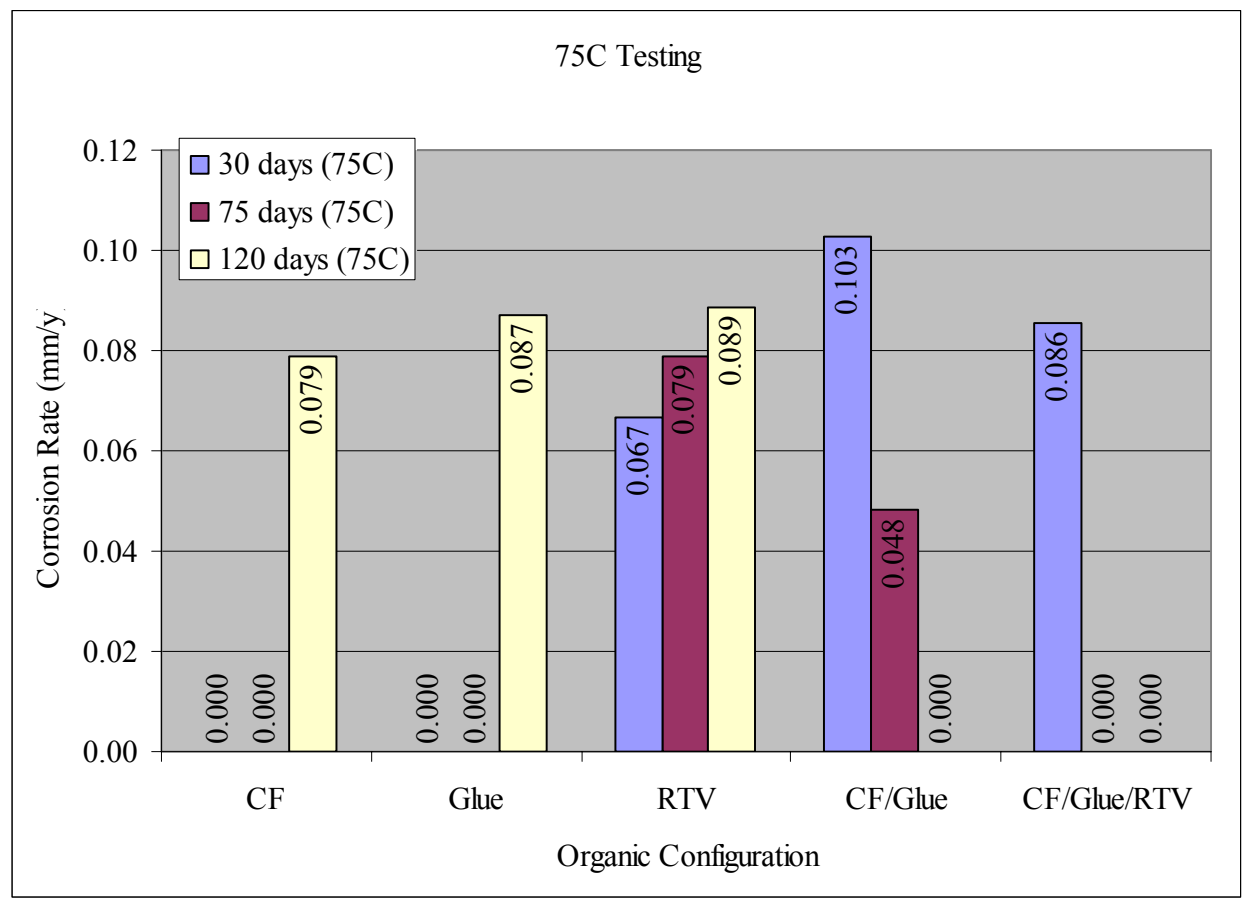

Figure 15: Corrosion Rates for Lead Coupons Exposed to Condensed Water Cells at $75^{\circ} \mathrm{C}$ for Re-Exposed Coupons and 120-Day Coupons

The experimental test matrix was developed to determine the effect of organic configuration, temperature, humidity and the effect of durations of exposure on the corrosion of lead in a model 9975 nuclear materials package. The corrosion rate data can be used to infer the effect of each of these discrete variables on the lead corrosion response.

The RTV sealant was the most corrosive organic species in the testing. Silicone sealants are based on mixtures of fillers (e.g., silica), silicone polymers, cross linking components, and catalysts. The polymer has a siloxane backbone, i.e., Si-O-Si, with alkyl and alkoxy or acetoxy pendant groups. The latter are readily hydrolyzed to silanol groups $(\mathrm{SiOH})$ which form larger chains by condensation and loss of alcohol or acetic acid. When the organic groups polymerize, a volatile species is generally released - the most common being acetic acid. The RTV $n$ the model 9975 package may contribute to the acetic acid within the package. However, the geometry of the package is such that the RTV is not in intimate contact with the lead, and the 
other components are the likely major contributors to the corrosion of the lead.

The PVAc glue was the next most aggressive species in the testing. The PVAc used for the 9975 assembly is not cross-linked and thus softens as its temperature is raised above room temperature, and it is less resistant to moisture and humidity than thermosetting resins. The PVAc glue is suspected to the primary source of acetic acid in the model 9975 package. The humidity and the temperatures within the package are sufficient to degrade the PVAc glue, particularly if incompletely cured during the manufacturing process. The PVAc glue is nearly in intimate contact with the lead shielding in the package, with sufficient vapor space in between to allow for build-up of acetic acid emissions. In addition, the $\mathrm{CO}_{2}$ and $\mathrm{H}_{2} \mathrm{O}$ within this vapor space are sufficient to support the corrosion reactions as well as to continue to degrade the PVAc.

The temperature also had an effect on the corrosion response of the lead. The coupons exhibited faster corrosion at higher temperatures than at room temperatures. There was a pronounced effect of condensed water as the coupons exposed in the cells with condensed water exhibited much higher corrosion rates. This can be specifically compared for the RTV configurations, where the corrosion rates doubled as a function of moisture and temperature.

The corrosion of the lead was also determined to be a function of the duration of exposure. The corrosion rates did not maintain a linear rate as expected per the corrosion mechanism as expected. This may have been due to the depletion of reactants for the longer exposures or due to the incongruity of the initial condition of the organic samples. It has been suggested that replenishment of the acetic acid is necessary for the corrosion reaction to continue. ${ }^{(19)}$ However, only minimal amounts of acetic acid, e.g. 1000ppb, are necessary to significantly increase the corrosion rate of lead. 
However, the coupons that were re-exposed after opening and closing in specific situations exhibited higher corrosion than the coupons that had complete 120-day exposures. This was particularly seen in the ambient humidity conditions, where the moisture content would have been replenished when opened and closed.

\section{CONCLUSIONS AND RECOMMENDATIONS}

The data can be used to draw several conclusions on the corrosion of the lead shielding in the model 9975 package. The testing confirmed that the organics of the model 9975 package cause corrosion of the lead shielding through acetic acid emissions. The RTV sealant was determined to the most aggressive in the experiments, followed by the PVAc glue. In the 9975 package, the PVAc glue was determined to be the most aggressive due to it's proximity in the design. The curing process of the PVAc glue is a key parameter for the lead corrosion. Poorly cured PVAc glue during package construction will lead to greater acetic-acid emission as it continues to cure in the package or during degradation in the warm, moist environment of the package

The condition considered most representative of the package conditions is that of the coupon exposed to the $\mathrm{CF} /$ glue organic exposed in the ambient humidity conditions. The $\mathrm{CF} /$ glue laminate in the package is nearly in intimate contact with the lead shielding as in the test setup. In addition the package will have high relative humidity conditions, but is not expected to have condensed water due to the heat. The water can be in the vapor space, or physisorbed on the surfaces with the CF. The corrosion rate of lead when exposed to these conditions was 2 mpy and is recommended as a bounding conditions for package performance calculations. This is considered a bounding condition due to the relatively aggressive nature of the test setup in comparison with the model 9975 package. In contrast to the more benign conditions in the 
model 9975 package, the experiments were done in small volume containers with a relatively large lead metal surface area exposed. In addition, the organic materials was also exposed within the small volume container and was subject to degradation over a much larger surface area exposed and consequently would lead to greater acetic acid emission. Lastly, the extremely aggressive PVAc glue in the experimental setup were large in volume relative to the test container, and also not completely cured. It is expected that the $2 \mathrm{mpy}$ rate will diminish over time if the primary source of acetic acid is the continued curing of a poorly cured glue. Additionally, it is expected that the opening and closing of the package will allow the acetic acid vapor to escape thereby temporarily stalling the corrosion process, while replenishing the carbon dioxide and moisture required to support the reaction.

\section{ACKNOWLEDGEMENTS}

The authors gratefully acknowledge Karen R. Hicks for performing the experiments and technician support throughout the project. The author also gratefully acknowledges W.L.

Daugherty, T.E. Skidmore, K.J. Imrich, and A. Jurgenson for the technical support and analyses. 
WSRC-STI-2007-00668

\section{REFERENCES}

1. Subramanian, K.H. Mechanism for Corrosion of Lead Shielding in Model 9975 Package. Washington Savannah River Company, WSRC-TR-2005-00193 (2005).

2. Goodwin, F.E. Uhlig's Corrosion Handbook: Lead and Lead Alloys (New York: John Wiley \& Sons) (2000) http://www.knovel.com/knovel2/Toc.jsp?BookID=682\&VerticalID $=0$.

3. Blackshaw, S.M. and Daniels, V.D. Testing of Materials for Use in Storage and Display in Museums. The Conservator 3(18), (1979).

4. Calvert, J.B. Lead. University of Denver, Department of Physics, retrieved April 26, 2005, $<$ http://www.du.edu/ jcalvert/phys/lead.htm $>$

5. Edwards, R., Bordass, R., Farrell, D. Determination of Acetic and Formic Acid in Lead Corrosion Products by Ion-Exchange Chromatography. Analyst 122, 1517-1520 (1997).

6. Rocca, E., Rapin, C., Mirambet, F. Inhibition Treatment of the Corrosion of Lead Artifacts in Atmospheric Conditioned and by Acetic Acid Vapor: Use of Sodium Decanoate. Corrosion Science 46, 653-665 (2004).

7. Handbook of Chemistry and Physics. (Boca Raton: CRC Press) (1971).

8. ASTM B749-03. Standard Specification for Lead and Lead Alloy Strip, Sheet, and Plate Products. ASTM International (2003).

9. Diaz-Ortiz, A., et. al. Characterization of Celotex and Thermodynamic Calculations of the Formation of Corrosion Precursors on Beryllium. University of Texas at Austin Amarillo National Resource Center for Plutonium, ANRCP-1999-16 (1999).

10. Lillard, R.S., et.al. Preliminary Investigation into the Corrosion of Beryllium Exposed to 
WSRC-STI-2007-00668

Celotex and Water. Los Alamos National Laboratory, LA-UR\# 97-0859 (1997).

11. Arni, P.C., et. al. The Emission of Corrosion Vapours by Wood:I. Survey of the Acid-Release Properties of Certain Freshly Felled Hardwoods and Softwoods. Journal of Applied Chemistry 15, 305-313 (1965).

12. Arni, P.C., et. al. The Emission of Corrosion Vapours by Wood:II. The Analysis of the Vapours Emitted by Certain Freshly Felled Hardwoods and Softwoods by Gas Chromatography and Spectrophotometry. Journal of Applied Chemistry 15, 463-468 (1965).

13. Oddy,W.A. An Unexpected Danger in Display Museums Journal 173, 27-28 (1973).

14. Petrie, E.M. Handbook of Adhesives and Sealants (New York: McGraw-Hill) (2000).

15. Carraher, C.E., and Seymour, R.B. Polymer Chemistry (Boca Raton: CRC Press) (2000).

16. Wheeler, O.L., et. al. Molecular Weight Degradation of Polyvinyl Acetate on Hydrolysis Journal of Polymer Science 8(4), 409-423 (2003).

17. Storch, P.S. Exhibit and Materials Storage Handbook: Test Results Index and Materials Glossary. (Minnesota Historical Society) (2000).

18. Simpson, W.T. Equilibrium Moisture Content of Wood in Outdoor Locations in the United States and Worldwide. USDOA - Forestry Service, FPL-RN-0268 (1998).

19. Niklasson, A., et. al. Influence of Acetic Acid Vapor on the Atmospheric Corrosion of Lead. Journal of the Electrochemical Society 152(12), B519-B525 (2005). 